\title{
The Egyptian Revolution and the Politics of Histories
}

\author{
Hesham Sallam, Georgetown University
}

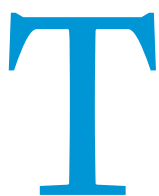

he Arab "revolutions"1 and the events surrounding them have posed a variety of theoretical challenges to political scientists. Popular uprisings have resulted in the ouster of long-standing autocrats in Tunisia, Egypt, Libya, and Yemen, and are seriously threatening the survival of incumbent authoritarian rulers in a region that once seemed immune to democratic change (Brumberg 2002; Fish 2002; Heydemann 2007; Posusney and Angrist 2005; Salamé 1994; Schlumberger 2007). These unforeseen developments pushed scholars of politics back to the drawing board to revisit dominant theoretical understandings of the drivers of regime change and stability (Albrecht and Bishara 2011; Bellin 2012; Blaydes and Lo 2012; Brownlee and Stacher 2011; Droz-Vincent 2011; Gause 2011; Goldstone 2011; Hoffman and Jamal 2012, Lynch 2011; Masoud 2011; Stacher 2012 ).

The challenges posed by the Arab revolutions, however, are not purely theoretical, but, equally importantly, pedagogical. For scholars and educators, the tasks of presenting a coherent, well-conceptualized understanding of the phenomena we often characterize as the "Arab revolutions," and explaining their theoretical significance vis-à-vis critical debates in the study of politics, are confounded by two underlying realities. First, the histories of these revolutions remain tentative, heavily politicized and, by implication, contested, thereby complicating any attempt to adjudicate between multiple competing claims concerning the determinants of these revolutions. Second, scholars confront a great deal of uncertainty about the character and scope of the phenomena under examination, given that the outcomes of the Arab revolutions are still openended, subject to interpretation, and continue to be fought out on the ground.

Nowhere are these challenges more apparent than in the case of Egypt, wherein various political players have actively promoted self-serving narratives about the origins of the January 25 Revolution, its temporal span, and reasons behind its alleged success. Relatedly, beyond the overthrow of longtime dictator Hosni Mubarak, the outcome of the revolution, whether substantively (and theoretically) meaningful political and social change has come to Egypt, is subject to a host of pending political battles; battles that until this moment appear largely unresolved.

Based on a case study of the Egypt's January 25 Revolution, this article argues that the open-ended character of these so-called revolutions challenges scholars to devise innovative pedagogical strategies that allow students to appreciate the extent to which the Arab revolutions should be viewed as living, contested phenomena rather than a set of well-defined, discrete outcomes. Furthermore, because the tensions between competing accounts of the revolutions, at least in part, mirror ongoing battles between various political actors in the countries of the region, highlighting and examining these tensions offer an invaluable lens for understanding the nature and contours of present political conflicts in these countries.

\section{THE POLITICS OF HISTORIES IN EGYPT}

Following 18 days of nationwide protests and occupation of downtown Cairo's Tahrir Square by anti-Mubarak activists, on February 11, 2011, then-vice president Omar Suleiman announced on Egyptian State Television that president Hosni Mubarak has resigned. Mubarak, who had ruled the country for nearly 30 years, left in charge the Supreme Council of the Armed Forces (SCAF), a body chaired by the minister of defense and composed of the country's most senior military leaders. SCAF rule ended formally on June 30, 2012, when it handed over power to president-elect Mohamed Morsi, a longtime figure inside the Muslim Brotherhood, Egypt's largest and oldest Islamist group. Morsi had narrowly defeated Mubarak's last prime minister Ahmed Shafiq in the second round of the presidential elections earlier that same month.

At first glance, the sequence of events that led to Mubarak's resignation seems uncontroversial and well documented by news reports and official statements. ${ }^{2}$ On closer examination, however, the story appears to be more complicated. Specifically, emergent accounts of the January 25 Revolution differ in the relative significance they assign to various relevant actors and events. Two areas of contention examined in this article pertain to the agency of military leaders in ejecting Mubarak out of office and the role of long-standing struggles for social and economic rights in advancing the revolution. Other contested aspects-not discussed in this article-include the role of international actors, especially the United States, in pressuring the former president to give up power; the role of the Muslim Brotherhood and Islamist activists in advancing and sustaining anti-Mubarak popular mobilization during the 18 days; and the importance of social networking sites to the success of the uprising. Accounts also differ with respect to defining of the temporal span of the revolution, namely whether the "January 25 Revolution" should be conceptualized only in reference to the 18 days of social upheaval that culminated in Mubarak's ouster or if it should encompass a wider time span. For instance, many observers argue that the definition of the revolution must be broadened to include the subsequent waves of mobilization and struggles for greater political, social, and economic rights; struggles that have since continued, if not intensified. 
With these discrepancies and tensions, how does one teach about Egypt's January 25 Revolution? One approach, informed by the tradition of hypothesis testing, is to treat each of the above competing claims about the roles of various factors in forcing Mubarak's ouster as an alternative hypothesis about the determinants of the revolution and its "success." In this context, lectures and seminar discussions are geared toward assessing how these various causal arguments fit togetherthat is, whether or not alternative claims crowd each other out and whether or not they are mutually exclusive-and toward evaluating the validity of each of these claims based on a critical understanding of the historical record. ${ }^{3}$

This approach is valuable because it opens up useful opportunities in the classroom to bridge theory and contemporary political realities, because, as explained, many of these above claims pertain to prior theoretical expectations about the determinants regime change and stability. At the same time, by proceeding on the assumption that there is one true, discernible causal sequence that generated the revolution, this approach overlooks the most interesting and fascinating aspect of the phenomena under examination, namely the broader political conflicts that have produced and shaped these competing accounts (or casual claims). What is it about post- the January 25 Revolution. Although some scholars might dismiss these discrepancies as mere "error" in the historical data, these are treated in this context as important political phenomena worthy of examination in their own right. Not only does such an effort deepen understanding of the origins of the revolution, but also, more importantly, it allows students to use these discrepancies as a lens for comprehending the nature of present political conflicts and struggles in Egypt, and their role in politicizing popular accounts of the revolution. This approach is also more likely to contribute to critical thinking inside and outside of the classroom about historical accounts promulgated through mainstream media about important political events and phenomena, not just the Arab revolutions.

To illustrate how such an approach can be implemented inside the classroom, the remainder of this article examines the aforementioned sources of discrepancies in emergent accounts of the January 25 Revolution with respect to their significance to the present-day politics and conflicts that are reinforcing and animating these tensions. The two illustrative examples examined in this article pertain to the role of the military in overthrowing Hosni Mubarak, and the significance of social and economic rights vis-à-vis the perceived success of the 18-day uprising. However, the approach can be

\section{This approach is also more likely to contribute to critical thinking inside and outside of the classroom about historical accounts promulgated through mainstream media about important political events and phenomena, not just the Arab revolutions.}

Mubarak politics that has made the role of the military in overthrowing the former president a subject of contestation? In what ways are ongoing conflicts in Egypt over distributive justice feeding into disagreements about the significance of labor demands in advancing the popular mobilization that ended 30 years of Mubarak rule? Bringing to light and grappling with these critical questions in the classroom demands a different approach, specifically one that seriously takes the need to understand the sources and implications of tensions in evolving accounts of the revolution. Such an approach, moreover, must proceed on a clear recognition that the "Egyptian Revolution" encompasses more than a just regimechange or a discreet outcome. Rather the January 25 Revolution, much like the rest of the Arab revolutions, can be better understood as what Jack Goldstone $(2001,173)$ refers to an "emergent phenomenon," encompassing a multifaceted process of intense social and political struggles akin to what the United States had witnessed during the 1960s. ${ }^{4}$

Another approach, informed by the interpretivist tradition, achieves this objective by relaxing the assumption that there is one true causal chain of events that led to the revolution. Thus, instead of orienting scholarly conversations toward assessing the validity of various competing claims to discern the "true" determinants of the revolution and its success, this approach is guided by an effort to comprehend the reasons and politics behind the tensions between rival narratives of applied beyond these two examples to a variety of different contentious, politicized aspects in the history of the January 25 Revolution, including, the roles of international actors, the Muslim Brotherhood, and social networking sites. In providing examples of potentially helpful resources that could be used for pedagogical purposes, I limit myself to Englishlanguage sources, but I also cite examples of Arabic-language sources to highlight useful opportunities for potential translations that could enhance future research and pedagogy.

\section{THE MILITARY: PROTECTED OR ABORTED THE REVOLUTION?}

"If I hadn't acted as I had and broadcast that tape, anything could have happened. Potentially, there could have been more bloodshed, with clashes between the army and the presidential forces. What happened in Syria or Libya could easily have happened in Egypt," writes Abdel Latif El-Menawy (2012, 286), the head of the news division at Egyptian State TV during the 2011 18-day uprising. El-Menawy's words came in his insider account of what was happening inside the circles of power in Egypt during Mubarak's final weeks in office. The tape to which he is referring contained the famous February 10, 2011, announcement that told the world that senior military leaders were convening without Mubarak, signaling that the military was now in charge and preparing for the president's formal departure from office. 
El-Menawy's book Tahrir: The Last 18 Days of Mubarak portrays the lead-up to Mubarak's departure as a struggle between two rival coalitions inside the ruling establishment and that competed for the ears of an old, detached, and ambivalent president. One coalition, which was intent on fighting until the end to keep the Mubarak presidency intact, included Mubarak's youngest son Gamal, who was allegedly being groomed to succeed his father, Mubarak's wife Suzanne Thabet, the president's close aides and top echelons inside the former ruling National Democratic Party, minister of interior Habib Al-Adly who had been in charge of the regime's coercive apparatus since 1997, and Mubarak's trusted minister of information and El-Menawy's boss during the uprising Anas El-Feki (98). On the other side of the equation were senior military leaders, including minister of defense Mohamed Hussein Tantawi and army chief of staff Sami Anan, along with Omar Suleiman, longtime head of the General Intelligence and whom Mubarak appointed vice president during his final weeks in office (99). Members of this camp, El-Menawy's narrative goes, had always been critical of attempts by Hosni Mubarak, his wife, and aides to pass the presidency onto Gamal and were eager to see the president respond positively to popular calls for change by stepping down. The image painted by potentially steer the political system toward a democratic outcome (38). The story of a regime divided between those who wanted to give change a chance versus those who were stubbornly committed the political status quo is apparent throughout El-Menawy's account. "The government was cracking," writes El-Menawy in reference to Field Marshal Tantawi's rejection of an alleged offer that Mubarak made him on January 29, 2011, to take on the post of vice president or deputy prime minister (139). The refusal of the military camp to become complicit in Mubarak's struggle for survival, the book tells us, is at the heart of the success of this revolution.

The conventional theoretical template developed by leading scholarship on democratic transitions is not the only thing that El-Menawy's narrative reinforces. It also bolsters the selfimage that military leaders have tried to promote in postMubarak Egyptian political arena, specifically an image of a benevolent force that intervened to protect and uphold the January 25 Revolution in the face of antireform regime elements. In other words, this dichotomy between regime softliners and hardliners that is often invoked political science research on transitions overlaps to a great extent with the military's public relations campaign throughout the course of its rule. This notion is most pronounced in Mostafa Bakri's

\section{The conventional theoretical template developed by leading scholarship on democratic} transitions is not the only thing that El-Menawy's narrative reinforces. It also bolsters the self-image that military leaders have tried to promote in post-Mubarak Egyptian political arena, specifically an image of a benevolent force that intervened to protect and uphold the January 25 Revolution in the face of antireform regime elements.

El-Menawy's account shows that the January 25 Revolution succeeded after military leaders sidelined the Gamal Mubarakled camp and pressured the president into resigning. The narrator, perhaps quite conveniently, attributes the success of these leaders, in part, to his principled decision to cooperate with them by broadcasting the military's statements on public television behind the backs of his civilian superiors, as he indicates in the previous excerpt, and by orienting the news programming toward the objectives of the "pro-revolution" military camp.

El-Menawy's account is compelling because it resonates with prior theoretical expectations about how transitions from authoritarian rule occur (O'Donnell and Schmitter 1986; Przeworski 1991), 5 particularly with respect to the centrality of internal regime cracks to initiating transitions away from authoritarian rule. In their classical study on the subject O'Donnell and Schmitter $(1986,19)$ argue that "there is no transition whose beginning is not the consequence-direct or indirect-ofimportant divisions within the authoritarian regime itself." Internal "regime cracks" dividing regime "hardliners" from reform-minded elements (or "softliners"), they argue, initiate a process of negotiations between those softliners and moderate opposition members over the political rules of the game (16). Strategic bargaining between the two sides could account (2011) of the revolution The Military and the Revolution: The Story of the Final Days, which was published in Arabic by the state-controlled Akhbar Al-Youm publishing house. A journalist and parliamentarian, Bakri quickly emerged after Mubarak's overthrow as one of the most vocal civilian supporters of SCAF's positions and policies. It is noteworthy that he was the only journalist to obtain an interview with Tantawi after he was retired by President Morsi in August 2012 (Bakri 2012). His account of the revolution is valuable because it is the closest thing we may ever have to a manual that explains what exactly the military wants the public to believe about the revolution and how it "succeeded."

Reinforcing El-Menawy's portrayal of a regime divided between progressive military officers and the uncompromising, corrupt authoritarian elements that surrounded the president, Bakri's account of the January 25 Revolution goes even further. He asserts that military leaders had always opposed the Mubarak regime, its corruption, and its efforts to groom Gamal Mubarak to succeed his father (8-9), and that the army was simply waiting for the "right moment" to announce its position (23). ${ }^{6}$ That moment was apparently the outbreak of the protests that eventually turned into the 18-day uprising, which ended with Mubarak's resignation. Bakri suggests that the army's plan during the lead-up to the revolution was never 
to stay on the sidelines as Mubarak prepares his son to succeed him. He claims that the army had anticipated the outbreak of mass protests in response to a prospective transfer of power from Hosni Mubarak to his son Gamal, and that the deployment plan it had implemented during the 18 days was put into place well before the uprising (36). Reading Bakri's account would leave the uncritical observer with the impression that the army was the revolution's guarding angel, and that its decision to "side with the protesters" was the decisive factor in forcing Mubarak's ejection from office.

Setting aside the holes and absurdities in these two accounts, which are too many to review here, 7 the emergence of such narratives from individuals close to the centers of power is indicative of how the history of the January 25 Revolution has become one of the major arenas for warfare between wielders of power and their challengers in Egypt.

The narrative purporting that the army has "protected the revolution" emerged in tandem with military leaders' brutal crackdown campaign against political dissent during the year plus that followed Mubarak's downfall through emergency laws, military trials against civilians, laws banning demonstrations and strikes, virginity tests, and the chronic use of deadly force against unarmed protesters. ${ }^{8}$ Meanwhile, the SCAF refused to handover power to a transitional civilian council, insisted on dictating the terms of the transition, shielded Mubarak's coercive apparatus from meaningful institutional reforms, and showed great reluctance to cooperate with efforts to prosecute former regime officials for past wrong-doing. The same revolutionary discourse that had once depicted the military as the ally of the people during the 2011 uprising through the infamous chant al-geesh wal-sha'b eid wahda "the army and the people are one hand united," was now purporting that the military council is but an extension of the Mubarak regime, chanting yalla ya masrienzel min darak, el tantawi howa mubarak ("lets go, Egyptian, leave your home [to protest, for] Tantawi is [the same as] Mubarak"). ${ }^{9}$

Interestingly, both accounts respond to the challenges that the military faced in managing waves of political dissent that sought to resist SCAF's apparent efforts to limit the scope of political change through a variety of strategies and tactics. ${ }^{10}$ By the fall of 2011, the actions of military forces on the ground shattered the conventional myth that the Egyptian army would never point a weapon against its own people. Social networking sites were circulating images and footage of armed forces' violence against civilians, including those of armored vehicles running over protesters near State Television on October 9, 2011, and in many other incidents. ${ }^{11}$

In some ways, the military's narrative of the revolution, as embodied by El-Menawy and Bakri's respective accounts, is steered toward mitigating the popular outcry against the army's abuses by portraying its leaders as the heroes who saved the day during the 2011 popular uprising. "If we really wanted to wage war against the Egyptian people," the narrative goes, "we would have done so during the critical moments of the eighteen-days." It is not surprising, therefore, that SCAF consistently prefaced its responses to popular challenges to its authority with a reminder that it took the side of the revolution against Mubarak during the 18-day uprising, evok- ing the same narrative that El-Menawy and Bakri convey. This theme was evident in the opening lines of Field Marshal Tantawi's speech on November 23, 2011, in response to the outbreak of one of the most dramatic post-Mubarak clashes between security forces and anti-SCAF protesters in Cairo and major cities between November 19 and 24, 2011..$^{12}$ In fact, shortly following his retirement in August 2012, Tantawi echoed El-Menawy's excerpt quoted above, saying: "If it were not for [our] wisdom, our fate would have been just like that of Libya or Syria. Look at all these civil wars and the blood that is being spilled. It was incumbent upon us, as army leaders, to make Egypt avoid this fate ... We protected the revolution, did not fire one bullet, and were partial to the people" (Bakri 2012).

As popular calls for bringing down the military council intensified in the aftermath of the November 2011 clashes, known as the "Mohamed Mahmoud Street battles," the military sent yet another reminder to the Egyptian public about its so-called heroic revolutionary role during the 18 -day uprising. On December 4, 2011, news reports stated that social networking sites users were circulating leaked footage showing then-SCAF member Ismail Etman being received by Abdel Latif El-Menawy at State Television building on February 11, 2011. In the clip, which was reportedly prepared by the military's morale affairs division, ${ }^{13}$ Etman accompanies El-Menawy to the control room and hands him the tape that contained Vice President Suleiman's famous announcement that Mubarak has resigned. ${ }^{14}$ The message behind the leaked video was clear: Mubarak's ouster is the doing of the military, and allegations that the military has been working against the revolution are unfounded.

The timing of the Bakri and El-Menawy accounts is revealing. The two books came out after opposition to the military had gained strength in the fall of 2011, and when revolutionary movements and activists began touting the view that the army was working to keep Mubarak's authoritarian practices and institutions intact. Bakri's book was released less than two months after it was reported that Mohamed Hussein Tantawi's testimony in Mubarak's trial steered away of acknowledging that the president ordered the use of force against protesters during the 18 -day uprising. ${ }^{15}$

Not only did Tantawi's long-awaited testimony disappoint families of protesters killed during the uprising, because it upheld the argument that Mubarak was not complicit in ordering their deaths, it also challenged the myth that the military had been trying to promote that the "army protected the revolution." Until that time, SCAF had been engaged in a heavy media campaign to convince Egyptians that military leaders went out of their way and took on many personal risks to side with the revolutionaries in their standoff with Mubarak. SCAF head Tantawi had stated publicly in May 2011 that members of the military council convened during the early phases of the uprising and decided collectively that "no, we will not open fire on the people." ${ }^{16}$ Yet, the fact that Tantawi's testimony in the Mubarak trial denied that an order was given to open fire, brought to the forefront of public discussion the question of who exactly did the army protect the revolutionaries from? 
It takes a lot of diligence to overlook the fact that Bakri's and El-Menawy's respective books were carefully designed to respond to these competing pressures and various accusations that the military was confronting in the fall of 2011. Both Bakri and El-Menawy advance the argument that the military's decision not to fire on protesters was part of a deliberate, conscious decision and not a manifestation of indifference or a strategy to "play it both ways." The two narratives convey this idea, while dispelling the charge that Mubarak ordered the military to open fire against protesters-a charge that military leaders had denied on multiple occasions. "The military made a deliberate decision not to open fire against protesters," the story goes, "but at no point were they were asked to do so." Because there was never a moment in which the military turned down an order to fire at protesters, since the order was supposedly never made, the two authors use a great deal of creativity in revealing and underscoring the military's intent to with the revolutionaries, quite opportunistically, after Mubarak's downfall was a fait accompli. ${ }^{17}$ Chronic confrontations between revolutionary movements and military forces were pushing observers to revisit and reinterpret the posture of the military vis-à-vis anti-Mubarak protesters during the 18-day uprising. For example, one video clip that circulated in the media during the summer of 2011 showed military officers clearing the way for armed men who were preparing to attack protesters in Tahrir Square on February 2, 2011, in what was famously dubbed "the battle of the camels." ${ }^{18}$ Did the officers simply wait on the sidelines to watch the Mubarakists and the revolutionaries fight it out with the intention of eventually siding with the winner, whoever it is?

As such questions were being posed, reports began proliferating in the media about the vast economic empire that the military commanded-a once-taboo topic-speculating that the army was engaged in a battle with its own people to preserve

\section{It takes a lot of diligence to overlook the fact that Bakri's and El-Menawy's respective books were carefully designed to respond to these competing pressures and various accusations that the military was confronting in the fall of 2011.}

avoid using force against protesters. On one hand, El-Menawy makes that revelation by casually citing a conversation between Field Marshal Tantawi and General Anan with President Mubarak. "They told the President, unambiguously, and unprompted, that they would not be able to use violence against the demonstrators if they were asked to do so ... They were afraid that Gamal might encourage his father to issue such an order" [Emphasis mine] (269). Bakri, on the other hand, was more creative in revealing the military's conscious commitment to refrain from using of force against protesters. He cites a remark by Anan at a dinner with a US government official in Washington, DC, on January 27, and in which he stated that the army would not use violence against Egyptians if its units were to be deployed on the streets (37). Bakri's account, quite resourcefully, even includes a direct response to those who wonder about the counterfactual that Mubarak would have asked the military to use violence against protesters. He reveals a conversation between a flight attendant and General Sami Anan, who was flying back to Egypt after an official visit to Washington, DC, during the early phases of the uprising. "He [the flight attendant] asked... What if the president issues an order to the armed forces to use violence against the protesters?! General Anan responded: We will not implement the order. The armed forces are part of the people and they would never accept that. Our mission is to protect the protesters and public facilities" (7).

Demonstrating that the army's "peaceful" posture toward the protesters was the product of a deliberate choice was imperative from the perspective of the SCAF. The notion that military leaders did not confront a moment in which they were forced to choose between the revolution and their commander in chief reinforced the view that the army only sided its long-standing economic privileges. The military in Egypt has long-controlled a diverse set of heavily subsidized revenue generating economic enterprises, the profits of which are not returned to state coffers and are not subject to any meaningful form of accountability or transparency. ${ }^{19}$ Many believe that these activities are rampant with corruption. In November 2011, the SCAF-sponsored government launched an effort to build consensus around a set of proposed constitutional articles, including ones that set the military's budget and activities beyond the reach of conventional parliamentary oversight and accountability. ${ }^{20}$ That the military was now openly fighting to secure the nondemocratic position of its economic empire pushed observers to reassess the view that military leaders pressured Mubarak out of office, not to save the revolution, but to control (if not abort) it to defend the army's wealth and unusual economic privileges from popular demands for real change inside state institutions.

As confrontations between the military and its challengers continued, SCAF responded with a variety of strategies, most visibly repression. At the heart of these strategies was also an effort to promote a self-empowering narrative of the January 25 Revolution; one that dispels the accusations of their rivals. Reinforcing this idea, Bakri closes the introduction of his account by stating: "Despite the media campaigns and political actions that are targeting the armed forces, the truth is always stronger than any allegations or lies. These truths include the role that the army has carried since the very beginning of the revolution until today" (4).

On August 12, 2012, news broke out that president Mohamed Morsi retired the country's most senior military officers, including Tantawi and Anan, signaling the effective end of SCAF's direct role in day-to-day governance. ${ }^{21}$ On their 
retirement Morsi bestowed them with the Order of the Nile, the highest state honor. A few months later, about $64 \%$ of Egyptian voters approved a draft constitution that was prepared by a body dominated by the Muslim Brotherhood and its allies. ${ }^{22}$ The constitution rendered the military's budget and activities beyond the reach of conventional parliamentary oversight. To date, no senior military leader stood trial for any wrongdoing committed during SCAF's rule between February 11, 2011, and June 30, 2012.

As political figures expressed their anger at the decision to give SCAF's leaders an honorable exit after all the abuses the army has committed against revolutionary activists and protesters throughout their rule, the response of Egypt's new civilian leadership was animated by the contested history of the January 25 Revolution. A statement by Prime Minister Hesham Qandil read: "President Morsi's decision ... comes out of
Partisans of distributive justice, on the other hand, have responded by arguing that social and economic demands have played a major role in sowing the seeds of the revolution, as suggested by the famous slogan of the January 25 protests, which turned into the mass uprising that toppled Mubarak: "Bread, freedom and social justice." Many have argued that although Egyptian workers did not participate in 18-day uprising as part of an organized initiative-given the fact that regime loyalists and allies have long dominated the only legal national trade union-Egyptian workers played a major role in the uprising as evidenced by the concentration of antiregime mobilization in working class cities. ${ }^{26}$ Whereas mainstream media narratives have focused on Tahrir Square as the site of resistance to the Mubarak regime during the uprising, some have claimed that it was the nationwide labor unrest that spread throughout the country that tilted the balance in favor of the

\section{As political figures expressed their anger at the decision to give SCAF's leaders an honorable exit after all the abuses the army has committed against revolutionary activists and protesters throughout their rule, the response of Egypt's new civilian leadership was animated by the contested history of the January 25 Revolution.}

respect and appreciation for the Supreme Council of Armed Forces, and Field Marshal Mohamed Hussein Tantawi, and General Sami Anan, and the leaders of the main [military] divisions, which supported the glorious January 25 Revolution, and took on a critical role in protecting the revolution and securing its success." ${ }^{23}$ Even as the SCAF was no longer the mover and shaker of day-to-day Egyptian politics-or so it seemed-the narrative of the wielders of power about the January 25 Revolution continued and entered into new political battles, taking on new meaning and significance.

\section{LABOR AND THE SOCIAL AND ECONOMIC ORIGINS OF THE REVOLUTION}

The role of the military is but one contentious aspect in emergent accounts of the January 25 Revolution and that continues to color post-Mubarak Egyptian politics. As the mobilization of Egyptian workers continued following Mubarak's demise in demand for greater social and economic rights, ${ }^{24}$ advocates of distributive justice and their adversaries within the ruling classes have battled over the significance of the role of workers and socioeconomic demands in initiating and advancing the revolution.

In the aftermath of the 18-day uprising, elite discourse has often portrayed labor action aimed at securing more humane wages and working conditions as manifestations of counterrevolutionary, special interests-driven schemes to paralyze the Egyptian economy. On one hand, public officials and elites contended that labor strikes and sit-ins were selfish attempts by a minority of Egyptians to exploit the state of unrest that surfaced in the wake of Mubarak's downfall by holding economic production hostage for the sake of securing narrow material gains. ${ }^{25}$ revolution. Activist Hossam el-Hamalawy (Haddad 2011) states: "What pushed matters in our favor and pushed Hosni Mubarak to realize ... that he had to leave power, were the beginning of labor strikes on the Wednesday and Thursday [February 9-10, 2011] prior to the Friday he stepped down ... The entry of the working class as an independent social force with its independent general strikes ... [is] what ended the regime of Hosni Mubarak." 27

The "labor-empowering" account of the revolution emerged in a context in which post-Mubarak governments sought to contain labor mobilization through a variety of measures, including a SCAF-sponsored law banning labor strikes and protests in the spring of 2011. Arguing that labor was the decisive factor in the success of the revolution also posed a serious challenge to the abovementioned account that wielders of powers have tried to advance and that says that the revolution's success is first and foremost attributed to the military's decision to side with the protesters. For example, Kamal AbuEita, longtime labor activist and the head of the Independent Federation of Trade Unions stated in an interview: "With all due respect to other points of views, such as those that say for example that it was all about the army's intervention, I believe that the [general] strikes is what hastened Mubarak's departure, preventing further bloodshed." ${ }^{28}$

This narrative also emerged in tension with the dominant view, which mainstream international media amplified, that the revolution was led by a set of tech-savvy upper-middle class youth who were driven by idealistic convictions with little commitment to ideology or class. "Under this banner of "youth" the "yuppies" and upper middle-class young people are portrayed as the quintessential representative of this uprising," writes Rabab El-Mahdi (2011a) in her sharp critique of 
Western portrayals of the Egyptian uprising. Similarly, Sameh Nagiub (2011), a leading member of Egypt's Revolutionary Socialists, faults the media for sidelining the participation of the country's working class in the uprising: "[O]rdinary working-class people dominated the battlefields, increasingly so with every passing week ... Of course, the media versions of the events would give an opposite view. The star "revolutionary" interviewees were all middle-class, universityeducated youth of one coalition or the other, all beaming with pride at being considered heroes of the revolution."

That many people began associating the effort to advance the January 25 Revolution with upper middle-class youth also coincided with the proliferation of the term shabab el facebook ("the youth of the Facebook") in Egyptian media to describe the major protagonists in the story of the 18-day uprising. ${ }^{29}$ The subtle implication of this characterization was that those who were responsible for anti-Mubarak mobilization were a group of idealistic, "pure," nonpartisan young people who did not seek to advance a particular social or political agenda. "They were not the youth of any particular ideology or leaning," the logic goes, "they were the youth of Facebook." This resonated with the aforementioned discourse that accused workers engaged in strikes and sit-ins of attempting to hijack ing to the class prejudice of the latter. But more importantly, the media strategy of the wielders of power were, in effect, writing (or perhaps rewriting) the history of the January 25 Revolution with respect to its class composition.

Resonating with a wide literature that linked regimestability to economic performance, $3^{30}$ the labor-centered narrative highlights the structural conditions that created a permissive environment for a mass uprising in Egypt. It underscores the eroding ability of the Egyptian state to deliver on its traditional commitments to important social groupsthrough subsidies, price controls, guaranteed employment, and social services-as a result of the global economic recession, and decades of corrupt-ridden neoliberal economic reforms that alienated workers and deepened socioeconomic grievances in society. ${ }^{31}$ Given these realities, it was not surprising, therefore, that it was the victims of economic neoliberalization among workers and the middle-class who took a visible lead in routinizing the tradition of protests and contentious political action during the decade that preceded the revolution, ${ }^{32}$ and who arguably played the decisive role in ending Mubarak's three-decade rule.

The centrality of socioeconomic grievances as a mobilizing factor in the revolution is also recognized in the account

\section{The thrust behind the narrative that privileges the roles of socioeconomic grievances and labor demands in advancing the 18-day uprising is in no small part the result of an effort by Egyptian Left and partisans of distributive justice to deepen the revolution's social and economic depths.}

the revolution to advance their own narrow interests, suggesting that workers demands were tangential to the 2011 popular uprising. The reference to "Facebook" also suggested that lowincome communities that did not enjoy the same access to high-tech tools were, at best, supporting actors in the story of the toppling of President Mubarak. The state-sponsored media has often exploited this narrative to dismiss any political or moral parallels between the protests that led to Mubarak's demise and those that challenged authority in the postMubarak period. For example, promilitary commentators in media outlets often invoked sightings of the poor and "street kids" at anti-SCAF protests and sit-ins to assert that these efforts were not led by the same well-groomed, smartphonecarrying, young individuals who had sparked the January 25 Revolution, but rather by a bunch of thugs paid for by counterrevolutionary elements. For example, reflecting on media portrayals of the November 2011 Mohamed Mahmoud Street battles, Lucie Ryzova (2011) writes: "Egyptian mainstream middle class culture can hardly relate to most of the frontline fighters. This is what will keep giving the state and state-allied media an upper hand in defining them as thugs ("baltagiyya") whenever the camera gets uncomfortably close." In other words, state media's strategy created a wedge between those who took to the streets and upper middle-class Egyptians watching the coverage of the protests from home by appeal- that Wael Ghonim (2012) presents in his memoir Revolution 2.o. Ghonim is the famed Google executive who administered the Facebook page, "We Are All Khaled Said," which is believed to have played a major role in spreading the initial call for the January 25 protests before it turned into the 18-day uprising that ousted Mubarak. His account of the revolution mostly centers on the role of Facebook in helping activists and concerned citizens overcome Mubarak's coercive apparatus, as well as their own fear to speak out against the immense police brutality that citizens were subjected to during Mubarak's final decade in office. Ghonim acknowledges that his decision to preface the call for the January 25 protests with a reference to social and economic issues was based on his realization that concerns about repression and human rights alone would not be an effective mobilizing message. He writes: "I deliberately included poverty, corruption, and unemployment in the title because we needed to have everyone join forces: workers, human rights activists, government employees, and others who had grown tired of the regime's policies. If the invitation to take to the streets had been based on solely on human rights, then only a certain segment of Egyptian society would have participated" (137).

The thrust behind the narrative that privileges the roles of socioeconomic grievances and labor demands in advancing the 18-day uprising is in no small part the result of an effort by 
Egyptian Left and partisans of distributive justice to deepen the revolution's social and economic depths. Attributing ownership of the revolution to ordinary working class Egyptians can also be viewed as an act of resistance against a ruling elite consensus that is poised to preserve the fundamentals of the Mubarak-era economic policies. Thus, the struggle to define the history of the January 25 Revolution in reference to its social and economic roots is likely to continue and to take on new functions, especially as the President Morsi-sponsored government prepares to conclude a $\$ 4.8$ billion loan agreement with the International Monetary Fund (IMF) that is poised to preserve the orientation of the Egyptian economy left by the previous regime. ${ }^{33}$ The struggle is also shaped by a reality in which the Muslim Brotherhood-controlled presidency is attempting to reinvent the state-dominated system of labor representation inherited from the Mubarak era to the marginalization of efforts to establish independent labor unions that are not beholden to the agendas of those in power. ${ }^{34}$

\section{THE REVOLUTION AS A LIVING PHENOMENON}

The tensions surrounding emergent accounts of the Arab revolutions offer classroom discussions a valuable lens for understanding the nature and boundaries of contemporary political conflicts in these countries. The analysis presented here demonstrates how evolving political battles in Egypt could be usefully situated in the contestation over the history of the January 25 Revolution with respect to two questions: the role of the military and that of social and economic demands in advancing the revolution. The same approach could be extended to other important aspects in the history of the January 25 Revolution. For instance, understanding the role of international actors, most notably the United States, in influencing the outcome of the 18-day uprising is complicated by a reality in which successive wielders of power in the post-Mubarak era have sought to cast their challengers among revolutionary movements as unpatriotic forces backed by foreign powers such as the United States. The question of the role of outsiders' powers is also confounded by the interest of important actors in Washington to demonstrate that the US government stood on the right side of history during the Egyptian uprising in its aftermath. ${ }^{35}$ Similarly, intensifying conflicts between the Mus$\lim$ Brotherhood and its challengers during the past two years have pushed observers close to the Egyptian political arena to constantly visit and revisit the role of the Muslim Brotherhood during the uprising. On the one hand, as Muslim Brotherhood leaders confronted accusations of striking underhanded deals with the SCAF at the expense of revolutionary movements, ${ }^{36}$ the group's sympathizers and partisans have constantly reminded their opponents of the heroic role that the Brotherhood's youth played in defending Tahrir Square from the violent attacks of pro-Mubarak thugs during the 18-day uprising. The Brotherhood's challengers, on the other hand, often cite the fact that the group was the last to join antiMubarak protests during the 18-day uprising only after the fall of Mubarak's coercive apparatus, and the first to depart after the military council took power-not to mention recurring allegations that the group was secretly negotiating with the Mubarak regime behind closed doors during the uprising. ${ }^{37}$ Put simply, the politics and conflicts of the present are constantly writing and rewriting the history of the January 25 Revolution.

Bringing these complexities and nuances of the Arab revolutions to the classroom requires that we approach them, not as a set of well-defined, discrete outcomes that can be discussed in past tense, but as a set of "emergent phenomena" (Goldstone 2001, 173). Specifically, it demands that we treat them as an array of inconclusive, open-ended struggles that are actively competing to define the meaning, scope, and appropriate expectations of the social and political transformations that are currently sweeping many of the countries of the Arab world.$^{38}$ The politics surrounding the contestation of histories and narrative of what we call revolutions present one critical arena in which these struggles are taking place.

\section{ACKNOWLEDGMENTS}

The author would like to thank Jason Brownlee for commenting on an earlier version of this article.

\section{NOTES}

1. Although none of the Arab countries where autocrats have been recently ousted exhibit compelling evidence that they have undergone the type of transformations that live up to conventional social scientific definitions of "revolutions," I use the term "revolution" with the assumption that it refers to an emergent phenomenon rather than a discreet outcome (Goldstone 2001,173-74). Observers have used different terms to characterize the political and social transformations that have swept the Arab world in the wake of the toppling of long-standing autocrats and the emergence of large-scale protest waves challenging authoritarian rulers since 2011. International media has often relied on the term "Arab Spring" to describe these transformations. The term, however, uncritically suggests parallels between these events and other historical examples of popular mobilization that have been described using the term "spring," such as the "Prague Spring" of 1968 (see Gelvin 2012: 32-33). The term the "Arab uprisings" is perhaps more precise to the extent that it does not evoke any such parallels, and that it accurately captures the state of nationwide protests and civil disobedience that many countries in the region experienced in the last two years, irrespective of whether or not such mobilization led to the ousting of incumbent autocrats. The term, however, is limited in that it does not fully capture the pending, open-ended struggles for transformative change that have followed the toppling of autocrats in countries like Tunisia, Egypt, and Libya.

2. For summaries of these events, see El-Ghobashy (2011), Shehata (2011), and Shokr (2011).

3. The use of historical evidence in constructing causal arguments is a subject of wide discussion in political science. See for example, Brady and Collier (2010), Büthe (2002), Capoccia and Ziblatt (2010), George and Bennett (2005), Elman and Elman (1997), Geddes (2003), Isacoff (2005), Kreuzer (2010), Lustick (1996), Mahoney and Rueschemeyer (2003), Tetlock and Lebow (2001), and Thies (2002),

4. My thanks go to Jason Brownlee for bringing that comparison to my attention.

5. For critiques, see Carothers (2002), and McFaul (2002).

6. For background on the military's relationship with civilian leaders and other security agencies prior to the January 25 Revolution, seeAmar (2012), Cook (2007), and Kandil (2012).

7. On El-Menawy's book, see commentary by Mahdi Mostafa (2012), and on Bakri's, see commentary by Ibrahim (2011).

8. See Amnesty International (2011) and Goldberg (2011).

9. For more on political slogans of the January 25 Revolution, see Colla (2012).

10. For more on these strategies, see El Amrani (2012).

11. For a summary of major incidents of violence committed by security forces under SCAF rule, see Eskandar (2012). Mosireen Collective, an Egyptian nonprofit media collective, compiled various testimonies and footage pertaining to abuse committed by security personnel against unarmed civilians throughout the course of SCAF's rule. These clips, 
many of which contain English subtitles, can be accessed online via http://www.youtube.com/user/Mosireen/videos?sort=dd\&view= o\&flow=list (Last accessed January 7,2013$)$.

12. The speech can be accessed online via http://www.youtube.com/ watch?v=8eolcYoLsf 4 (Last accessed January 7, 2013).

13. Kassab (2011)

14. The clip can be accessed via http://www.youtube.com/watch?v= 6v3sdvUqhho (Last accessed January 7, 2013).

15. The text of the testimony can be found in Al-Mamluk (2012).

16. Badr (2011)

17. For example, Jason Brownlee (2011) points out that SCAF officers seemed to have backed Mubarak until it was clear that he would no longer be able to contain the protesters, citing a SCAF official telling a Washington Post reporter: "At the beginning, we gave the presidential institution the full opportunity to manage events. If it were able to succeed, nothing would have happened ... [His forces] were incapable of responding to the events...On Feb. 10, there were demonstrations that amounted to millions of people all over the country."

18. The clip can be accessed via http://www.youtube.com/watch?v= jRojCFa773w (Last accessed January 7, 2013).

19. For more on the military's involvement in the economy see Abul-Magd (2011), Harb (2003), Marshall (2012), Marshall and Stacher (2012), and Sayigh (2012).

20. See Brumberg and Sallam $(2012,5)$.

21. For background on the politics surrounding this decision, see Sallam (2012)

22. For results constitutional referendum results, see Stamboliyska (2012). For a good summary of the controversial articles in the constitution see Attalah (2012).

23. See "The presidency denies..." (2012).

24. For more on labor mobilization in Egypt after the uprisings, see Alexander (2012), Beinin (2012), and Kennedy (2012)

25. See Sallam (2011) for an account of these debates.

26. See Beinin (2011), and Haddad (2011).

27. See Haddad (2011). A similar argument was made by Sameh Nagiub (2011).

28. Sallam (2012)

29. For a discussion of the role of social networking sites in the Egyptian uprising, see Herrera (2012)

30. See for example Alesina et al. (1996), Dunning (2005), and Haggard and Kaufman (1995),

31. For more on economic liberalization policies in Egypt prior to the revolution see Kienle (2004), King (2007), Mitchell (1999), and Sfakianakis (2004).

32. For more on waves of labor protests prior to the revolution, see Beinin and el-Hamalawy (2007), El-Mahdi (2011b), and Solidarity Center (2010) For the history of state-labor relations in Egypt, see Posusney (1997).

33. See Hyde and Salah-Ahmed (2012) for a discussion of Morsi's economic posture. See Hanieh (2012) for a discussion of the role of international financial institutions in Egypt following the uprising.

34. For a discussion of the Morsi presidency's relations with independent unions, see Bishara (2012)

35. For an excellent account of US-Egyptian relations as they relate the question of democratic change before and after Mubarak's overthrow, see Brownlee (2012)

36. For more on the history of the Muslim Brotherhood's relations with successive Egyptian rulers, see Eskandar (2013).

37. Former Muslim Brotherhood Guidance Bureau member Mohamed Habib claims that the group sent Mohamed Morsi, who would later become president, and would-be parliamentary speaker Saad El-Katatny to negotiate with vice president Omar Suleiman during the course of the 2011 uprising. See El-Badri and Saleh (2012). For a Muslim Brotherhood account on the January 25 Revolution and its lead-up, see article by Muslim Brotherhood Guidance Bureau member, Mohamed Abdel Rahman Al-Morsi (2011). Moreover, in 2011, Al-Jazeera news channel featured a series of multipart interviews with political figures who shared their perspective on how the events of the uprising unfolded. Guests included individuals close to the Muslim Brotherhood, including Osama Yassin, the group's "field coordinator" during the uprising, and Safwat Hegazy, a prominent preacher allied with the Muslim Brotherhood. The clips for these interviews can be retrieved online through Al-Jazeera's youtube channel page: http://www.youtube.com/user/aljazeerachannel? feature $=$ watch $($ Last accessed January 7,2013$)$.

38. For a critical discussion of this point, see roundtable debate on the language of revolution in Egypt. Sedra, Springborg, Stacher, Sabra and Colla (2012). Also see Beinin (2013).

\section{REFERENCES}

Abul-Magd, Zeinab. 2011. "The Army and the Economy in Egypt." Jadaliyya, December 23. http://www.jadaliyya.com/pages/index/3732/the-army-andthe-economy-in-egypt.

Albrecht, Holger, and Dina Bishara. 2011. "Back on Horseback: The Military and Political Transformation in Egypt." Middle East Law and Governance $3(1-2): 13-23$.

Alesina, Alberto, et al. 1996. "Political Instability and Economic Growth." Journal of Economic Growth 1 (2): 189-211.

Alexander, Anne. 2012. "The Egyptian Workers' Movement and the 25 January Revolution." International Socialism Journal 133. http://isj.org.uk/ index.php4 $? \mathrm{id}=778$ (accessed January 7,2013$)$.

Al-Mamluk, Mahmoud. 2012. "The Text of the Field Marshal's Testimony in the Protesters' Murder Case." (Arabic) Youm7, June 2. http://www1. youm7.com/News.asp?NewsID $=694460 \&$ SecID $=12$ (accessed January 7 , 2013).

Al-Morsi, Mohamed Abdel Rahman. 2011. "Lights on the Egypt's Revolution, January 25." (Arabic) Ikhwan Online, September 12. http://www. ikhwanonline.com/new/Article.aspx?SecID $=390 \&$ ArtID $=91072$ (last accessed January 7,2013$)$.

Amar, Paul. 2012. "Why Mubarak is Out?" In The Dawn of the Arab Uprisings: End of an Old Order? eds. Bassam Haddad, Rosie Bsheer, and Ziad AbuRish, 83-90. London: Pluto Press.

Amnesty International. 2011. Egypt: Broken Promises: Egypt's Military Rulers Erode Human Rights. London: Amnesty International. http://www. amnesty.org/en/library/asset/MDE12/053/2011/en/47be269e-b67a-42f4835b-787f91044e04/mde120532011en.pdf (accessed January 7, 2013).

Attalah, Lina. 2012. "The Draft Constitution: Some Controversial Stipulations." Egypt Independent, December 1. http://www.egyptindependent.com/ news/draft-constitution-some-controversial-stipulations (accessed January $7,2013)$.

Badr, Malika. 2011. "Field Marshal Tantawi: We Will Not Allow for the Destruction of the Nation." (Arabic) Al-Masry Al-Youm, 17 May 2011. http:// www.almasryalyoum.com/node/439906 (accessed January 7, 2013).

Bakri, Mostafa. 2011. The Military and the Revolution: The Story of the Final Days (Arabic). Cairo: Akhbar Al-Youm Publishing House

Bakri, Mostafa. 2012. "First Interview with Field Marshal Tantawi." (Arabic) El-Osboa, October 21. http://elaosboa.com/ArticleDetails.aspx?Aid= 23352 (accessed January 7, 2013).

Beinin, Joel. 2011. "Egypt's Workers Rise Up." The Nation March 7-14. http:// www.thenation.com/article/158680/egypts-workers-rise (accessed January 7, 2013).

Beinin, Joel. 2012. The Rise of Egypt's Workers. Carnegie Endowment for International Peace Paper. http://carnegieendowment.org/files/egypt_labor.pdf (accessed January 7,2013 ).

Beinin, Joel. 2013. "Was There a January 25 Revolution?" Jadaliyya, January 25 2013. www.jadaliyya.com/pages/index/9766/was-there-a-january-25revolution (accessed February 12, 2013).

Beinin, Joel, and Hossam el-Hamalawy. 2007. "Strikes in Egypt Spread from Center of Gravity.” Middle East Report Online, 9 May 2007. http://www. merip.org/mero/meroo50907 (accessed January 7, 2013).

Bellin, Eva. 2012. "Reconsidering the Robustness of Authoritarianism in the Middle East: Lessons from the Arab Spring." Comparative Politics 2 (January): $127-49$.

Bishara, Dina. 2012. "Egyptian Labor between Morsi and Mubarak." ForeignPolicy.com, November 28. http://mideast.foreignpolicy.com/posts/2012/11/ 28/power_grab_on_egypts_unions (accessed January 7, 2013).

Blaydes, Lisa, and James Lo. 2012. "One Man, One Vote, One Time? A Model of Democratization in the Middle East." Journal of Theoretical Politics 24 (1): $110-46$.

Brady, Henry E., and David Collier. 2010. Rethinking Social Inquiry: Diverse Tools, Shared Standards. Lanham, MD: Rowman \& Littlefield. 
Brownlee, Jason. 2011. "Egypt's Incomplete Revolution: The Challenge of Post-Mubarak Authoritarianism." Jadaliyya, 5 July 5. http://www. jadaliyya.com/pages/index/2059/egypts-incomplete-revolution_thechallenge-of-post (accessed January 7,2013 ).

Brownlee, Jason. 2012. Democracy Prevention: The Politics of the US-Egyptian Alliance. New York: Cambridge University Press

Brownlee, Jason, and Joshua Stacher. 2011. "Change of Leader, Continuity of System: Nascent Liberalization in Post-Mubarak Egypt.” APSA Compara tive Democratization Newsletter 9: 4-9.

Brumberg, Daniel. 2002. "The Trap of Liberalized Autocracy.” Journal of Democracy 13 (4): 56-68.

Brumberg, Daniel, and Hesham Sallam. 2012. The Politics of Security Sector Reform in Egypt. United States Institute of Peace Special Report (2012).

Büthe, Tim. 2002. "Taking Temporality Seriously: Modeling History and the Use of Narratives as Evidence." American Political Science Review 96 (3): 481-94

Capoccia, Giovanni, and Daniel Ziblatt. 2010. "The Historical Turn in Democratization Studies: A New Research Agenda for Europe and Beyond." Comparative Political Studies 43 (8-9): 931-68.

Carothers, Thomas. 2002. "The End of the Transition Paradigm." Journal of Democracy 13 (1): 5-21.

Colla, Elliott. 2012. “The People Want.” Middle East Report 263: Summer http://www.merip.org/mer/mer263/people-want (accessed January 7, 2013).

Cook, Steven A. 2007. Ruling but Not Governing: The Military and Political Development in Egypt, Algeria, and Turkey. Baltimore: Johns Hopkins University Press.

Droz-Vincent, Philippe. 2011. "Authoritarianism, Revolutions, Armies and Arab Regime Transitions." The International Spectator 46 (2): 5-21.

Dunning, Thad. 2005. "Resource Dependence, Economic Performance, and Political Stability." Journal of Conflict Resolution 49 (4): 451-82.

El Amrani, Issandar. 2012. "Sightings of the Egyptian Deep State." Middle East Report Online 1 January 2012. http://www.merip.org/mero/meroo10112 (accessed January 7, 2013).

El-Badri, Haytham, and Doha Saleh. 2012. "Mohamed Habib: I Told Badie that Negotiating with Omar Suleiman is Dishonorable for the Brothers." (Arabic) Youm7, January 23. http://www.youm7.com/News.asp?NewsID = 584692\& (accessed January 7, 2013).

El-Ghobashy, Mona. 2011. "The Praxis of the Egyptian Revolution." Middle East Research and Information Project 258: 2-13.

El-Mahdi, Rabab. 2011a. "Labour Protests in Egypt: Causes and Meanings." Review of African Political Economy 38 (129): 387-402.

El-Mahdi, Rabab. 2011b. "Labour Protests in Egypt: Causes and Meanings." Review of African Political Economy 38 (129): 387-402.

Elman, Colin, and Miriam Fendius Elman. 1997. "Diplomatic History and International Relations Theory: Respecting Difference and Crossing Boundaries." International Security 22 (1): 5-21.

El-Menawy, Abdel Latif. 2012. Tahrir: The Last 18 Days of Mubarak. UK: Gilgamesh Publishing.

Eskandar, Wael. 2012. "Year of the SCAF: a Timeline of Mounting Repression." Jadaliyya, March 9. http://www.jadaliyya.com/pages/index/3091/ year-of-the-scaf_a-timeline-of-mounting-repression (accessed January 7 , 2013).

Eskandar, Wael. 2013. "Brothers and Officers: A History of Pacts." Jadaliyya, January 25, 2013. http://www.jadaliyya.com/pages/index/9765/brothersand-officers_a-history-of-pacts (accessed February 12, 2013).

Fish, M. Steven. 2002. "Islam and Authoritarianism." World Politics 55 (1): 4-37.

Gause, F. Gregory, III. 2011. "Why Middle East Studies Missed the Arab Spring: The Myth of Authoritarian Stability.” Foreign Affairs 9o (4): 81-90.

Geddes, Barbara. 2003. Paradigms and Sand Castles: Theory Building and Research Design in Comparative Politics. Ann Arbor: University of Michigan Press.

Gelvin, James L. 2012. The Arab Uprisings: What Everyone Needs to Know. New York and Oxford: Oxford University Press.

George, Alexander, and Andrew Bennett. 2005. Case Studies and Theory Development in the Social Science. Cambridge, MA: MIT Press.

Ghonim, Wael. 2012. Revolution 2.o: The Power of the People Is Greater Than the People in Power. London: Houghton Mifflin Harcourt.
Goldberg, Ellis. 2011. "Mubarak without Mubarakism: Why Egypt's Military Will Not Embrace Democracy." Foreign Affairs.com, February 11. http:// www.foreignaffairs.com/articles/67416/ellis-goldberg/mubarakismwithout-mubarak (accessed January 7,2013 ).

Goldstone, Jack. 2001. "Toward a Fourth Generation of Revolutionary Theory." Annual Review of Political Science 4: 139-87.

Goldstone, Jack A. 2011. "Understanding the Revolutions of 2011: Weakness and Resilience in Middle Eastern Autocracies." Foreign Affairs 90 (3): 8-16.

Haddad, Bassam. 2011. "English Translation of Interview with Hossam ElHamalawy on the Role of Labor/Unions in the Egyptian Revolution." Jadaliyya, April 3o. http://www.jadaliyya.com/pages/index/1387/englishtranslation-of-interview-with-hossam-el-ha (accessed January 7, 2013).

Haggard, Stephan, and Robert R. Kaufman. 1995. The Political Economy of Democratic Transitions. Princeton, NJ: Princeton University Press.

Hanieh, Adam. 2012. "Egypt's 'Orderly Transition'? International Aid and the Rush to Structural Adjustment." In The Dawn of the Arab Uprisings: End of an Old Order? eds. Bassam Haddad, Rosie Bsheer, and Ziad Abu-Rish, 124-36. London: Pluto Press.

Harb, Imad. 2003. "The Egyptian Military in Politics: Disengagement or Accommodation?" The Middle East Journal 57 (2): 269-9o.

Herrera, Linda. 2012. "Egypt's Revolution 2.o: The Facebook Gactor." In The Dawn of the Arab Uprisings: End of an Old Order? eds. Bassam Haddad, Rosie Bsheer, and Ziad Abu-Rish, 91-96. London: Pluto Press.

Heydemann, Steven. 2007. Upgrading Authoritarianism in the Arab World. Saban Center for Middle East Policy at the Brookings Institution. http:// www.brookings.edu/ /media/research/files/papers/2007/10/arabworld/ 10arabworld.pdf (accessed February 12, 2013).

Hoffman, Michael, and Amaney Jamal. 2012. "The Youth and the Arab Spring: Cohort Differences and Similarities." Middle East Law and Governance 4 (1): 168-188.

Hyde, Maggie, and Amira Salah-Ahmed. 2012. "Egypt's Economic Reform Plan: Revolutionary Social Justice, or More of the Same?" Egypt Independent, November 29. http://www.egyptindependent.com/news/egypt-seconomic-reform-plan-revolutionary-social-justice-or-more-same (accessed January 7, 2013).

Ibrahim, Rihab. 2011. "Mostafa Bakri and Stories of the Revolution. Who is Writing the History? And for whom?" (Arabic) Al-Badil, October 22 http://elbadil.com/\%D8\%B1\%D8\%AD\%D8\%A7\%D8\%A8-\%D8\%A5\%D8\%A8 \%D8\%B1\%D8\%A7\%D9\%87\%D9\%8A\%D9\%85-\%D8\%AA\%D9\%83\%D8\%AA \%D8\%A8-\%D9\%85\%D8\%B5\%D8\%B7\%D9\%81\%D9\%89-\%D8\%A8\%D9\%83 \%D8\%B1\%D9\%8A-\%D9\%88\%D8\%AD\%D9\%83\%D8\%A7\%D9\%8A\%D8\%A7 $\% \mathrm{D} 8 \% \mathrm{AA}-\% \mathrm{D} 8 \% \mathrm{~A} 7$ (accessed January 7,2013 ).

Isacoff, Jonathan B. 2005. "Writing the Arab-Israeli Conflict: Historical Bias and the Use of History in Political Science." Perspectives on Politics 3 (1): 71-88.

Kandil, Hazem. 2012. Soldiers, Spies and Statesmen: Egypt's Road to Revolt. Brooklyn, NY: Verso.

Kassab, Mohamed. 2011. "General Ismail Etman: I Am not Responsible for the Leaking of the Video of the Airing of Mubarak's Resignation Speech." (Arabic) Al-Badil, December 4. http://elbadil.com/\%D8\%A7\%D9\%84\%D9 \%84\%D9\%88\%D8\%A7\%D8\%A1-\%D8\%A5\%D8\%B3\%D9\%85\%D8\%A7\%D8 \%B9\%D9\%8A\%D9\%84-\%D8\%B9\%D8\%AA\%D9\%85\%D8\%A7\%D9\%86\%D9\%84\%D8\%B3\%D8\%AA-\%D9\%85\%D8\%B3\%D8\%A6\%D9\%88\%D9 \%84\%D8\%A7-\%D8\%B9\%D9\%86-\%D8\%AA\%D8\%B3\%D8\%B1 (accessed January 7,2013$)$.

Kennedy, Gillian. 2012. "Egyptian Doctors' Strike and the Quest for Bread, Freedom, and Social Justice." Jadaliyya, November 17. http://www. jadaliyya.com/pages/index/8452/egyptian-doctors-strike-and-thequest-for-bread-fr (accessed January 7, 2013).

Kienle, Eberhard. 2004. "Reconciling Privilege and Reform: Fiscal Policy in Egypt, 1991-200o." In Networks of Privilege in the Middle East: The Politics of Economic Reform Revisited, ed. Steven Heydemann, 281-96. London: Palgrave Macmillan.

King, Stephen J. 2007. "Sustaining Authoritarianism in the Middle East and North Africa." Political Science Quarterly 122 (3): 433-59.

Kreuzer, Marcus. 2010. "Historical Knowledge and Quantitative Analysis: The Case of the Origins of Proportional Representation." American Political Science Review 104 (2): 369-92.

Lustick, Ian S. 1996. "History, Historiography, and Political Science: Multiple Historical Records and the Problem of Selection Bias." American Political Science Review 90 (3): 605-18.

Lynch, Marc. 2011. "After Egypt: The Limits and Promise of Online Challenges to the Authoritarian Arab." Perspectives on Politics 9 (2): 301-10. 
Mahoney, James, and Dietrich Rueschemeyer, eds. 2003. Comparative Historical Analysis in the Social Sciences. New York: Cambridge University Press.

Marshall, Shana, and Joshua Stacher. 2012. "Egypt's Generals and Transnational Capital." Middle East Report 262: 12-18.

Marshall, Shana. 2012. "Egypt's Other Revolution: Modernizing the Military." Jadaliyya, February 10. http://www.jadaliyya.com/pages/index/4311/egyptsother-revolution_modernizing-the-military-i.

Masoud, Tarek. 2011. “The Road to (and From) Liberation Square.” Journal of Democracy 22 (3): 20-34.

McFaul, Michael. 2002. "The Fourth Wave of Democracy and Dictatorship." World Politics 54: 212-44.

Mitchell, Timothy. 1999. "Dreamland: The Neoliberalism of Your Desires." Middle East Report 210 (Spring).

Mostafa, Mahdi. 2012. "El Menawy a Leader of the Revolution" (Arabic), Ahram Al-Arabi, February 2. http://digital.ahram.org.eg/articles. aspx?Serial $=791265 \&$ eid $=804$ (accessed January 7,2013$)$.

Nagiub, Sameh. 2011. "Egypt's Unfinished Revolution." International Socialist Review 79 (September-October). www.isreview.org/issues/79/featureegyptianrevolution.shtml (accessed February 12, 2013).

O’Donnell, Guillermo A., and Philippe C. Schmitter. 1986. Transitions from Authoritarian Rule: Tentative Conclusions about Uncertain Democracies. Baltimore: Johns Hopkins University Press.

Posusney, Marsha Pripstein. 1997. Labor and the State in Egypt: Workers, Unions, and Economic Restructuring. New York: Columbia University Press.

Posusney, Marsha Pripstein, and Michele Penner Angrist, eds. 2005. Authoritarianism in the Middle East: Regimes and Resistance. Boulder, CO: Lynne Rienner Publishers.

Przeworski, Adam. 1991. Democracy and the Market: Political and Economic Reforms in Eastern Europe and Latin America. New York: Cambridge University Press.

Ryzova, Lucie. 2011. "The Battle of Muhammad Mahmud Street: Teargas, Hair Gel, and Tramadol." Jadaliyya, November 28. http://www.jadaliyya com/pages/index/3312/the-battle-of-muhammad-mahmud-street teargas-hair- (accessed January 7,2013 ).

Salamé, Ghassan, ed. 1994. Democracy without Democrats. London: Tauris.

Sallam, Hesham. 2011. "Striking Back at Egyptian Workers." Middle East Report 41 (259): 20-25.
Sallam, Hesham. 2012. "Morsy, the Coup and the Revolution." Egypt Independent, August 15. http://www.egyptindependent.com/opinion/morsy-coupand-revolution (accessed January 7, 2013).

Sayigh, Yezid. 2012. Above the State: The Officers' Republic in Egypt. Carnegie Endowment for International Peace Paper, August. http:// carnegieendowment.org/files/officers_republic1.pdf (accessed January 7, 2013).

Schlumberger, Oliver (ed.). 2007. Debating Arab Authoritarianism: Dynamics and Durability in Nondemocratic Regimes. Palo Alto, CA: Stanford University Press.

Sedra, Paul, Robert Springborg, Joshua Stacher, Adam Sabra, and Elliott Colla. 2012. "Roundtable on the Language of Revolution in Egypt." Jadaliyya, August 12. http://www.jadaliyya.com/pages/index/6552/roundtableon-the-language-of-revolution-in-egypt (accessed January 7,2013 ).

Sfakianakis, John. 2004. "The Whales of the Nile: Networks, Businessmen, and Bureaucrats during the Era of Privatization in Egypt." In Networks of Privilege in the Middle East: The Politics of Economic Reform Revisited, ed. Steven Heydemann, 77-100. London: Palgrave Macmillan.

Shehata, Dina. 2011 “The Fall of the Pharaoh.” Foreign Affairs. 14 Apr. 2011. 12 Feb. 2013. http://www.foreignaffairs.com/articles/67687/dina-shehata/thefall-of-the-pharaoh (accessed February 12, 2013).

Shokr, Ahmad. 2011. "The 18 Days of Tahrir." Middle East Report 258: 14-19.

Solidarity Center. 2010. Justice for All: The Struggle for Worker Rights in Egypt. Washington, DC: Solidarity Center. http://www.solidaritycenter.org/files/ pubs_egypt_wr.pdf (accessed January 7 , 2013).

Stacher, Joshua. 2012. Adaptable Autocrats: Regime Power in Egypt and Syria. Palo Alto, CA: Stanford University Press

Stamboliyska, Rayna. 2012. "Egypt's Constitutional Referendum Results." Jadaliyya, December 25. http://www.jadaliyya.com/pages/index/9234/ egypt\%E2\%80\%99s-constitutional-referendum-results (accessed January 7 , 2013)

Tetlock, Philip E., and Richard Ned Lebow. 2001. "Poking Counterfactual Holes in Covering Laws: Cognitive Styles and Historical Reasoning." American Political Science Review 95 (4): 829-44.

"The Presidency Denies Placing Tantawi and Anan Under House Arrest and Confirms Their Appointment to the Presidential Team." 2012. (Arabic) State Information Service, August 14. http://www.sis.gov.eg/Ar/ Story.aspx?sid $=61027$ (accessed January 7, 2013).

Thies, Cameron G. 2002. "A Pragmatic Guide to Qualitative Historical Analysis in the Study of International Relations." International Studies Perspectives 3 (4): 351-72. 